\title{
Histo-Morphometric Compression Finding of the Small Intestine in Rats and Rabbit According to Different Foods
}

\author{
Eyhab RM Al-Samawy ${ }^{1}$, Diyar M.H.Kadhim² ${ }^{2}$ Ihab Abbas Taher ${ }^{1}$, Hekmat B Alhmadi ${ }^{1}$ and Mustafa \\ Salah Hasan ${ }^{3}$ \\ ${ }^{1}$ Anatomy Department, College of Medicine, AL Muthanna University, Iraq \\ ${ }^{2}$ Anatomy Department, College of Veterinary Medicine, AL-Muthanna University, Iraq \\ ${ }^{3}$ Department of Internal and Preventive Medicine, College of Veterinary Medicine, University of Fallujah, Iraq \\ *Corresponding author: drmustafasalah7@gmail.com
}

\begin{abstract}
Article History: 18-536 Received: December 10, $2018 \quad$ Revised: March 20, 2020 Accepted: June 15, 2020
\section{ABSTRACT}

In the present study, the histo-morphometric comparison study of small intestine in rats and rabbit was aimed. Ten of clinically healthy animals of both sexes were collected by Al-Simawa city, age ranged between 6month to 1 year, which was estimated according to the dental equation of the animals. The small intestine was cut and stained alternatively with Hematoxylin and Eosin (H \& E) and (Lilles Alchrome stain). The current study aims to discover the structures and measurement of small intestine belonging to these animals specifically their histo-morphometric textures. The anatomical studies revealed that small intestine of both animals consists of: duodenum, jejunum and ileum. Histological exam was showed that the wall of small intestine composed of four layers including: mucosa, submucosa, muscularis and serosa and adventitia. The epithelia of villi small intestine were simple columnar cells for each animal.
\end{abstract}

\section{Key words: Histology, Small intestine, Rats, Doudenum and Epithelium.}

\section{INTRODUCTION}

The small intestine was observed to be divided into (duodenum, jejunum and ileum). The duodenum was long and started at the pylorus region close to the stomach. The jejunum appeared to be convoluted or coiled, very long and occupied the abdominal floor between the stomach urinary bladder. The ileum was short and followed the jejunum and marked the end of the small intestine. The distal end of the ileum had a thick walled enlargement, Sacculus rotundus which mark the junction between the ileum, cecum and colon (Wise et al., 2003 and Cathy, 2006).

The major functions of the small intestine are digestion, secretion, and absorption. The small intestinal mucosa has several anatomic adaptations that serve to create an immense surface area with which to digest and absorb nutrients. These include the plicae circulares (intestinal folds), villi, and microvilli. The small intestinal mucosa is characterized by numerous, regularly distributed luminal papillary projections called villi. Villi are lined by columnar epithelial cells, enterocytes. Enterocytes have apical microvilli (brush border) (Thomas, 2005).
The chyme passes into the small intestine from the stomach. Flow into the small intestine is regulated by the pyloric sphincter. The small intestine is the place where the majority of digestion and absorption of nutrients occurs. The small intestine can be divided into three sections-duodenum, jejunum, and ileum. (Harkness and Wagner, 1995).

The duodenum is the first section and is the site of most digestion. Buffers are secreted from the pancreas into the small intestine to increase the $\mathrm{pH}$ to a more neutral level, as the stomach acids would make the digested food have a low $\mathrm{pH}$ level. In addition, a variety of enzymes are secreted by and into the small intestine to break down the food. These include proteolytic, lipolytic (fat digesting), and amylolytic (starch digesting) enzymes. (Lowe et al., 2000 and Charlotte, 2004).

The jejunum is the middle section of the small intestine. Many nutrients, such as amino acids, fatty acids, and glucose, are absorbed here. The last section of the small intestine is the ileum. In the ileum, the remaining digested nutrients are absorbed, as well as the B vitamins (Huang et al., 1999). The ileum is mainly to absorb vitamin $B_{12}$ and bile salts and whatever products of

Cite This Article as: Al-Samawy ERM, DMH Kadhim, IA Taher and HB Alhmadi, 2020. Histo-Morphometric compression finding of the small intestine in rats and rabbit according to different foods. Int J Vet Sci, 9(3): 433-437. www.ijvets.com (C2020 IJVS. All rights reserved) 
digestion was not absorbed by the jejunum. The wall itself is made up of folds, each of which has many tiny fingerlike projections known as villi on its surface. In turn, the epithelial cells that line these villi possess even larger numbers of microvilli. Therefore, the ileum has an extremely large surface area both for the adsorption (attachment) of enzyme molecules and for the absorption of products of digestion. (Kararli, 1995).

\section{MATERIALS AND METHODS}

\section{Animal source}

A total of ten mature animals of both sexes (5 rats and 5 rabbits) were used for this study. They were purchased from local market of Al-Samawaa city, Al Muthanaa coverment, Iraq. The animals were transported using laboratory rat cages to the department of veterinary anatomy laboratory, University Al-Muthanaa, Iraq.

The animals were acclimatized for three days prior to the research and had free access to elephant grass, commercial feed supplement and water. The animals were observed to be in good nutritional status on physical examination before euthanasia. They were all sedated using gaseous chloroform in a confined container and later sacrificed.

\section{Gross anatomy}

For each animal, an incision was made on the ventral midline immediately after sacrifice and the abdominal cavity was exposed. The small intestines were dissected from the mesenteric and spread in a straight line. The gross anatomical structures of the entire intestine were observed.

Photomacrographs were taken using a digital camera. Tissues samples were collected from the segments of the small intestine (Duodenum, Jejunum and Ileum) and fixed $10 \%$ in buffered formalin for histology.

\section{Histology}

The fixed tissues (duodenum, jejunum and ileum) were cut into blocks and identified. They were then dehydrated through a series of graded alcohols (70\%, $80 \%, 90 \%, 95 \%$ and $100 \%$ ). The blocks were cleared in xylene and then infiltrated with molten paraffin wax. Sections $(6 \mu \mathrm{m})$ microns thick were cut from embedded tissue using (Jung Rotary Microtome (model 42339). (Luna, 1968).

The tissues were then mounted on grease free clean glass slides. The slides were prepared at room temperature stained alternatively with Hematoxylin and Eosin (H \& E) and (Lilles Alchrome stain). The prepared slides were studied using light microscope (Olympus binocular microscope). Photomicrographs of the prepared slides mounted on the binocular microscope were taken using a digital microscopic objective. These pictures were then transferred to a computer and detailed studies were carried out (Bancroft and Stevens, 2010).

\section{RESULTS AND DISCUSSION}

Morphological aspect: The small intestine of animal studies was distinctly divided into three segments, namely the duodenum, jejunum and ileum. The three grossly divided parts of small intestine in the current studied animals were similarly observed in other studies such as (Kellow et al., 1986; Grant et al., 1989 and Gray \& Lewis, 2000).

The duodenum consisted of descending and ascending limbs forming U-shaped tube called duodenal loop. The pancreas observed between these limbs. The Ushape of duodenum in the current animals was commonly observed in the other (this result disagreement with other studies such as (Agur et al., 1999) those said the duodenum it was found to form an "S" shaped curve and also the (Nzalak et al., 2005; Bburaimoh and Ojo, 2012) mention the duodenum it found is a C-shaped or horseshoe-shaped structure.

The jejunum of the animals was organized grossly in the form of cone-shaped of spiral coils. The cone had centripetal coils, a sigmoid flexure and centrifugal coils. This jejunum shape was similar to other studies in squirre (Seyyedin and Nazem, 2017).

The third segment of the small intestine of the animals was the ileum which appeared the shortest part of the small intestine. It joined the jejunum cranially and extended caudally to join the cecum these result agreement with other studies such as (Agur et al., 1999, Seyyedin and Nazem, 2017).

\section{Histological aspect}

The small intestine appeared long convoluted tube, extends from the junction with stomach to joining point with the large intestine. Three segments were found in the small intestine of the studied animals, namely duodenum, jejunum and ileum these result agreement with other studies such as (Nzalak et al., 2015, Seyyedin and Nazem, 2017).

Duodenum: The organ showed microscopically the four classic known layers of a tube organ: mucosa, submucosa, muscularis and serosa (Fig. 1) and the dimensions of duodenum in rat and rabbit showing in (Table 1). These four layers appeared in the duodenum and other parts of the small intestine in all such as (Dellmann et al., 1987 and Călămar et al., 2017).

Tunicae mucosa: The duodenal mucous membrane in the animals showed three different parts (Fig. 2), that were lining epithelium (simple columnar cells) (Fig. 2), lamina propria (loose connective tissue with the presence of mucosal glands) (Fig. 2,1) and muscularis mucosa (two thick layers of smooth muscle arranged into inner circular and outer longitudinal bundles). The presence of two layers of muscularis mucosa in the duodenal mucosae of animals was similar to the findings observed in (Bacha W.J. and Bacha L.M. 20003). The mean thickness of this tunica in rat was $2014.2 \mu \mathrm{m}$, whereas, in the rabbit was $2313.1 \mu \mathrm{m}$.

Duodenal villi: They were finger-shaped mucosal projections which constructed from the lamina propria, smooth muscle fibers as well as the lacteal. The latter was blind ended lymphatic capillary that is lined by simple columnar epithelium in studied animals (Fig.1a) these result agreement with other studies such as (Wise et al., 2003; Cathy, 2006). 
Table 1: The dimensions of duodenum in rat and rabbit $(\mu \mathrm{m})$ (Mean \pm SE).

\begin{tabular}{lll}
\hline duodenum $(\mu \mathrm{m})$ & Species & Mean \\
\hline Tunica mucosa & Rat & 2014.2 \\
& rabbit & 2313.1 \\
Tunica submucosa & Rat & 1865.3 \\
& rabbit & 2334.1 \\
Tunica muscularis externia & Rat & 4752 \\
& rabbit & 5987 \\
Tunica serosa & Rat & 202 \\
& rabbit & 260 \\
Duodenal gland(diameter) & rat & 3178 \\
& rabbit & 5673.1 \\
villi (length) & rat & 7011.3 \\
& rabbit & 9034.7 \\
\hline
\end{tabular}

Table 2: The dimensions of jejunum in rat and rabbit $(\mu \mathrm{m})$ (Mean \pm SE).

\begin{tabular}{lll}
\hline jejunum $(\mu \mathrm{m})$ & Species & Mean \\
\hline Tunica mucosa & rat & 2531 \\
& rabbit & 2891 \\
Tunica submucosa & rat & 1542 \\
& rabbit & 1812 \\
Tunica muscularis externia & rat & 4421 \\
& rabbit & 4981 \\
Tunica serosa & rat & 160 \\
& rabbit & 200 \\
Crypts of lieberkuhn gland (diameter) & rat & 2399 \\
& rabbit & 2876 \\
Villi (length) & rat & 7890 \\
& rabbit & 8971 \\
\hline
\end{tabular}

Table 3: The dimensions of ileum in rat and rabbit $(\mu \mathrm{m})$ (Mean $\pm \mathrm{SE})$.

\begin{tabular}{lll}
\hline Ileum $(\mu \mathrm{m})$ & Species & Mean \\
\hline Tunica mucosa & rat & 1905 \\
& rabbit & 2106 \\
Tunica submucosa $(\mu \mathrm{m})$ & rat & 1324 \\
& rabbit & 1561 \\
Tunica muscularis externia & rat & 2307 \\
& rabbit & 2871.4 \\
Tunica serosa & rat & 140 \\
& rabbit & 180 \\
Villi (length) & rat & 3011 \\
& rabbit & 3422.1 \\
\hline
\end{tabular}

The lining epithelium of the villi was similar to those observed previously in the same organ these similarity with study (Thomas, 2005). The irregularity that observed in the mucosal surface could be due to the presence of duodenal villi intervening between the bases crypts of Lieberkühn. The mean length of villi in rat was $7011.3 \mu \mathrm{m}$ in rat, whereas, in rabbit about $9034.7 \mu \mathrm{m}$.

Duodenal crypts of lieberkühn: These were simple tubular glands called intestinal glands that were extended from the muscularis mucosa till the bases of the villi. They were lined by a simple columnar epithelium similar to the lining epithelium of the duodenal lumen (Fig. 2a). The mean diameter of gland in rat was $3178 \mu \mathrm{m}$ and in rabbit $5673.1 \mu \mathrm{m}$.

Tunicae submucosa: It was formed irregular dense connective tissue situated, beneath the muscularis mucosa, and the layer composed of large blood, lymphatic vessels. The Brunner glands that found in submucosa in mammals concert. The mean thickness of this tunica in rat was $1865.3 \mu \mathrm{m}$, whereas, in the rabbit was $2334.1 \mu \mathrm{m}$.

Tunicae Muscularis Externia: Underneath submucosa the muscular coat consists of the smooth muscles fibers arranged into two layers, the inner circular and the outer longitudinal layers in the studied animals (Fig.1a). Evenly the inner layer was thicker than the longitudinal layer over all parts of the duodenum. This finding was agreed with studies (Bburaimoh and Ojo, 2012) in wistar rats. The mean thickness of this tunica in rat was $4752 \mu \mathrm{m}$, whereas, in the rabbit was $5987 \mu \mathrm{m}$.

Serosa and adventitia: The layer appeared thin in thickness constructed by loose connective tissue covered by a layer of mesothelial cells (Fig. 1a). The serosa lined externally the muscularis. These findings were similarly recorded in other this result disagreement with (Harkness JE, Wagner JE. 1995 ) in wistar rats. The adventitia or outer layer consists of a serous membrane composed of connective tissue covered the free part of organ. The mean thickness of this tunica in rat was $202 \mu \mathrm{m}$, whereas, in the rabbit was $260 \mu \mathrm{m}$.

Jejunum: The microscopic examination of jejunum's wall showed similar histological layers of a tube organ (and the dimensions of jujenum in rat and rabbit showing in (Table 2; Fig.3, b).

Tunicae mucosa: The mucous membrane was thrown into large numerous long leaf-shaped villi that were arranged in a finger like projections in animals. The epithelial lining represented by single layer of tall columnar cells of both villi and crypts in the studied animals (Fig. 3b) which was in a good agreements with what was recorded by other result such as (Harkness JE, Wagner JE. 1995) in wistar rats. The mean length of villi in rat was $7890 \mu \mathrm{m}$, whereas, in rabbit about $8971 \mu \mathrm{m}$. The crypts of Lieberkühn were short and simple tubular ducts opened at the bases of villi occupying most of the thickness of the lamina propria till the muscularis mucosa (Fig. 3b). The mean diameter of gland in rat was $2399 \mu \mathrm{m}$ and in rabbit was $2876 \mu \mathrm{m}$. The lamina propria consists of loosely packed connective tissue containing blood vessels and muscle fibers (Fig. 3b) and such finding was comparable with that observed by other studies (Harkness JE, Wagner JE, 1995) in wistar rats.

The muscularis mucosa in the animals was poorly developed and composed of only a few bundles of circular muscle fibers (Fig. 1b). The mean thickness of this tunica in rat was $2531 \mu \mathrm{m}$, whereas, in the rabbit was $2891 \mu \mathrm{m}$.

Tunicae submucosa: The submucosa was a thicker layer of loose connective tissue possessed many blood vessels (Fig. 1b). The mean thickness of this tunica in rat was $1542 \mu \mathrm{m}$, whereas, in the rabbit was $1812 \mu \mathrm{m}$.

Tunicae muscularis externia: This layer was constructed of a thin outer longitudinal and a thick inner circular layers in the studied animals. Between these muscle bundles, fine dispersed narrow connective tissue layer containing many large blood vessels (Fig. 1b). The presence of two muscular layers in the present animals 

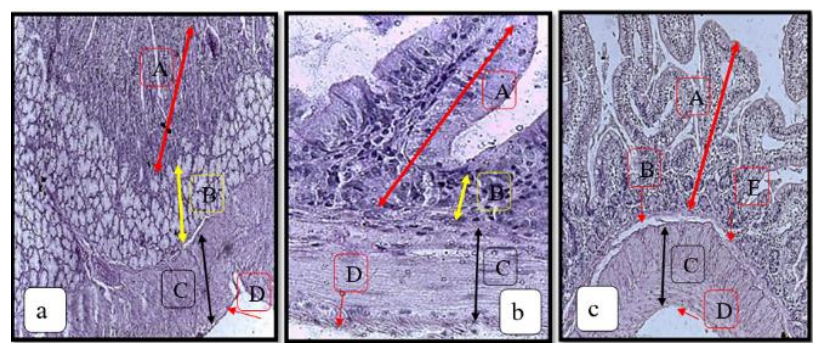

Fig. 1: Cross section of the small intestine wall of Rabbit showed mucosa (A), Submucosa (B), Muscularis (C), and serosa (D), mascularis mucosa (E) , (a) duodenum, (b) jejunum, (c) ileum H \& E, X100 (a) and (b), (c) X200.

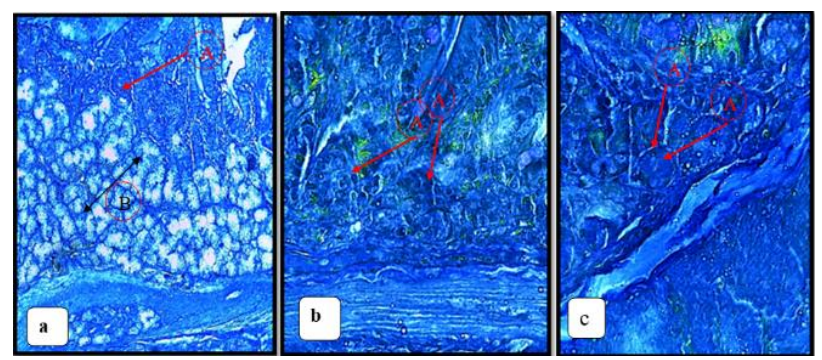

Fig. 2: Cross section of the small intestine wall of Rabbit showed: Crypts of Lieberkuhn (A), Brunner's glands (B) connective tissue (green), (a) duodenum, (b) jejunum, (c) ileum: Lilles Alchrome stain, X40.

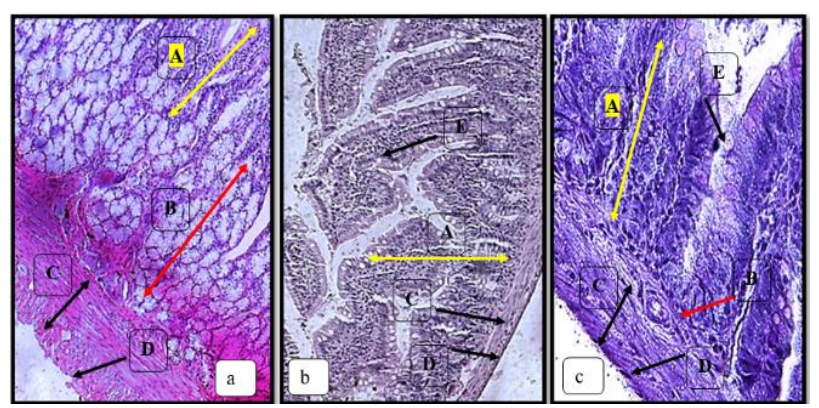

Fig. 3: Cross section of the small intestine wall of Rat showed mucosa (A), Submucosa (B), Muscularis (C), and serosa (D), goblet cells (E), (a) duodenum, (b) jejunum, (c) ileum $\mathrm{H} \& \mathrm{E}$, X100.

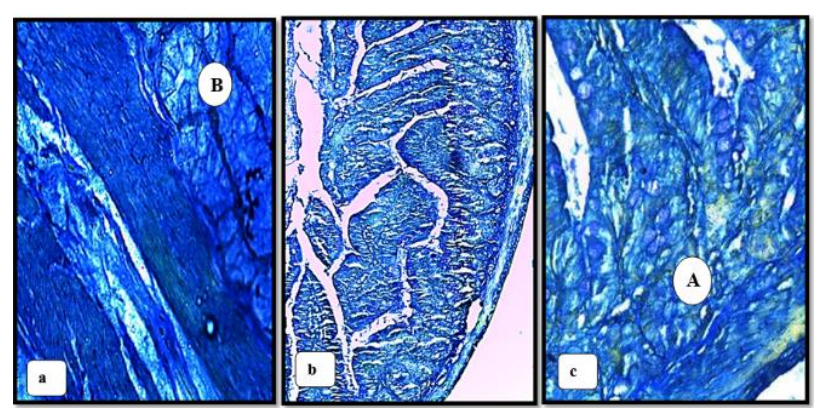

Fig. 4: Cross section of the small intestine wall of Rat showed: Crypts of Lieberkuhn (A), Brunner's glands (B) connective tissue (green), (a) duodenum, (b) jejunum, (c) ileum: Lilles Alchrome stain, $\mathrm{X} 40$.

was similarly recorded in other studies such as (Nzalak JO, N Wanmi, and MO Samuel 2015). The mean thickness of this tunica in rat was $4421 \mu \mathrm{m}$, whereas, in the rabbit was $4981 \mu \mathrm{m}$.
Tunicae Serosa: It was formed by layer of simple squamous epithelium under which was a thin layer of loose connective tissue (Fig. 1b). The mean thickness of this tunica in rat was $160 \mu \mathrm{m}$, whereas, in the rabbit was $200 \mu \mathrm{m}$.

Ileum: Similar to the previous tube like organs the microscopic examination of ileum's wall showed the four layers: mucosa, submucosa, muscularis and serosa (Fig. 4) and the dimensions of ileum in rat and rabbit showing in (Table 3).

Tunicae mucosa: The villi appeared small leaf-shaped arranged in a zig-zag pattern (Fig. 4c). Each villus was lined by an epithelium while its center contained connective tissue core and such construction was agreed with results of studies (Harkness JE, Wagner JE. 1995) in wistar rats. The villi were short and less numerous compared to those found previously in the jejunum and duodenum of the same investigated animals. The lining epithelium was simple columnar (Fig. 1c). The epithelium showed obviously higher number of goblet cells compared to those observed in both duodenum and jejunum. The mean length of villi in rat was $3011 \mu \mathrm{m}$, whereas, in rabbit about $3422.1 \mu \mathrm{m}$ Loose connective tissue observed in the propria just beneath the epithelial lining (Fig. 1c) which was similar to (Seyyedin and Nazem, 2017) in rats when a simple columnar epithelium supported by underlying connective tissue propria.

The muscularis mucosa was made of a thin outer longitudinal and a thick inner circular layers of smooth muscle fibers (Harkness and Wagner, 1995) in wistar rats. The mean thickness of this tunica in rat was $1905 \mu \mathrm{m}$, whereas, in the rabbit was $2106 \mu \mathrm{m}$.

Tunicae submucosa: This layer was formed of loose connective tissue with blood vessels and these findings agreed with that recorded in (Harkness and Wagner, 1995) in wistar rats. The mean thickness of this tunica in rat was $1324 \mu \mathrm{m}$, whereas, in the rabbit was $1561 \mu \mathrm{m}$.

Tunicae muscularis externia: The layer muscularis was made up of an inner circularly and an outer longitudinally arranged layers of smooth muscles bundles (Fig. 1c). This muscular arrangement was similar to that in (Seyyedin and Nazem, 2017) in rats. The mean thickness of this tunica in rat was $2307 \mu \mathrm{m}$, whereas, in the rabbit was $2871.4 \mu \mathrm{m}$.

Tunicae serosa: Layers serosa was a thin layer of loose connective tissue. Its external surface was lined by simple squamous epithelium (Fig. 4c). The mean thickness of this tunica in rat was $140 \mu \mathrm{m}$, whereas, in the rabbit was 180 $\mu \mathrm{m}$.

\section{REFERENCES}

Agur AMR, Lee MJ and Grant JCB, 1999. Grant's Atlas of Anatomy. $10^{\text {th }}$ Ed. London, UK: Lippincott Williams and Wilkins.

Bancroft JD and Stevens A, 2010. Theory and Practice of Histological Techniques. $2^{\text {nd }}$ Ed., Churchill Livingstone. New York pp: 356. 
Int J Vet Sci, 2020, 9(3): 433-437.

Bacha WJ and Bacha LM, 2000. Color Atlas of Veterinary Histology $2^{\text {nd }}$ Edn. Lippinocott, Willams and Wilkins, Baltimare Maryland pp: 148-149.

Bburaimoh AA and Ojo SA, 2012. Effects of Aluminium Chloride Exposure on the Histology of the Small intestine of Wistar Rats. Int J Appl Sci Technol 2: December, 2012.

Cathy AJ, 2006. Anatomy and physiology of the rabbit and rodent gastrointestinal system. eastside and exotic medical centre, PLLC $100^{\text {th }}$ Ave NE, WA 98034, USA pp: 9-14.

Călămar CD, Pătruică S, Dumitrescu G, et al., 2014. Morphohistological study of the digestive tract and the annex glands of Chinchilla laniger. Anim Sci Biotechnol, 47: 269-274.

Charlotte LO, 2004. Veterinary Histology VMED 7123, In: Online lecture notes. http://www.cvum.okstate.edu/ instruction/mmcurr/histologyReferenc pp: 1-17.

Dellmann HD and Brown BM, 1987. Textbook of Veterinary Histology $3^{\text {rd }}$ Ed Lee and Febiger, Phialadelphia pp: 209-253.

Grant JCB, Basmajian JV and Slonecker CE, 1989. Grant's method of anatomy: A clinical Problem-Solving Approach. $11^{\text {th }}$ Ed. London, UK: Williams and Wilkins.

Gray H and Lewis WH, 2000. Gray's Anatomy of the Human Body. $20^{\text {th }}$ ed. New York, NY: Bartleby.

Harkness JE and Wagner JE, 1995. The Biology and Medicine of Rabbits and Rodents. $4^{\text {th }}$ ed. Media, PA: Williams and Wilkins.

Heath JW, Young B and Burkitt HG, 1999. Gastrointestinal tract. In: Wheater's functional histology. $3^{\text {rd }}$ Ed. New York, Churchill Livingstone. pp: 247-70.

Hildebrand $M$ and Goslow GE, 2001. Analysis of vertebratestructure. 5thed. New York, John Wiley and sons Inc., pp: 201-17.
Huang X, Zhu HM, Deng CZ, et al., 1999. Gastroesophageal reflux: The features in elderly patients. World J Gastroenterol, 5: 421-423.

Kararli TT, 1995. Comparison of the gastrointestinal anatomy, physiology, and biochemistry of humans and commonly used laboratory animals. Biopharm Drug Dispos, 16: 35180.

Kellow JE, Borody TJ, Phillips SF, et al., 1986. Human interdigestive motility: Variations in patterns from esophagus to colon. Gastroenterology, 91: 386-395.

Lowe JA, deBlas C and Wiseman J, 2000. The Nutrition of the Rabbit, New York, NY: CABI Publications.

Luna IG, 1968. Manual of histology staining methods of thearmed force institute of pathology. 3rd ed. McGraw. Hill book company. New York, 33: 76-68

Nzalak JO, Wanmi N and Samuel MO, 2015. Anatomical and histological studies of the small intestine of the african giant rat (Cricetomys gambianus-water house)- II. Ann Experim Biol, 3: 20-26.

Seyyedin S and Nazem MN, 2017. Histomorphometric study of the effect of methionine on small intestine parameters in rat: an applied histologic study. Articles in "Folia Morphologica" are listed in PubMed.

Thomas C, 2005. Histology of the digestive system. In: The VM8054 Histology lecture notes Department of Veterinary Anatomy, Virginia-Maryland College of Veterinary Medicine.

Wise F, Simon O and Weyrauch KD, 2003. Morphology of Small Intestine of Weaned pig and a Novel Method for Morphometric Evaluation. Anatomia. Histologia Embryologia 32:102-109. 